\title{
Effect of Urea Briquettes in Combination of Organics on Root Growth and Nitrogen Losses in Rice Field
}

\author{
Rinky Roy ${ }^{*}$, R.K. Bajpai, VinayBachkaiya, Chandan Kumar Roy, \\ Khagesh Joshi and Sushma \\ College of Agriculture, Indira Gandhi Krishi Vishwavidyalaya, Raipur, Chhattisgarh, India \\ *Corresponding author
}

\section{Keywords \\ Nitrogen, Urea briquettes, \\ Organics, FYM, \\ Rajeshwari, \\ Irrigated rice, \\ Nitrogen losses, \\ Root volume, Root growth}

\section{Article Info}

Accepted:

12 December 2018

Available Online:

10 January 2019

\section{A B S T R A C T}

Nitrogenous fertilizers applied to soil undergo various physico-chemical and biological transformations due to influence of different enzymes and microbial activity and thereby become available to crops. The efficient use of nitrogen is recognized as an important production factor for rice production but it has always been a problem to raise its utilization rate by rice and to increase efficiency of absorbed nitrogen for grain production. Even with the best agronomic practices only $30-40$ percent of applied nitrogen is actually utilized by the crop. A field experiment was conducted in kharif 2017 at the Research cum Instructional Farm, Indira Gandhi Krishi Vishwavidyalaya, Raipur (C.G). Rice variety Rajeshwari was taken as test crop under irrigated condition. The experiment was laid out in randomized complete block design comprising of total 11 treatments; out of which, four treatments involving application of urea briquettes, another four treatments involving application of urea and rest three treatments involving application of briquettes of urea + FYM, urea + vermicompost and urea + neem cake as source of nitrogen along with varying doses of phosphorus and potassium. Each treatment was replicated four times. The influence of the different levels and sources of Non root growth and nitrogen losses was studied under different treatments. The results revealed that Nitrogen losses in irrigated rice were significantly influenced by the treatments. The concentration of nitrates and ammonia found in leachates in treatments involving urea+organics briquettes were found significantly lower compared to rest treatments. There was a progressive increase in root dry weight and volume with the advancement of crop growth stage. The effect of different nitrogen levels and sources was found statistically significant on root growth. The highest value of root volume and dry weight were found in in treatments involving urea+FYM briquettes application. The addition of organics in urea briquettes and deep placement of briquettes exhibited better root development and lower nitrogen losses which might be attributed to slow release of nitrogen and thus reducing the losses and thereby higher nutrients uptake and ultimately higher root biomass.

\section{Introduction}

Chhattisgarh is popularly known as "Rice Bowl of India" with an area of around 3.68 million hectares and production of 8.20 million tons under rice cultivation during kharif season which contributes $8.65 \%$ and $6.30 \%$ respectively of total acreage and 
production in India with productivity being $2020 \mathrm{~kg} \mathrm{ha}^{-1}$ in 2013-14 (Anonymous, 2015).

Nitrogen is the most important nutrient in irrigated rice production. Nitrogenous fertilizers applied to soil undergo various physico-chemical and biological transformations due to influence of different enzymes and microbial activity and thereby become available to crops.

The efficient use of nitrogen is recognized as an important production factor for rice production but it has always been a problem to raise its utilization rate by rice and to increase efficiency of absorbed nitrogen for rice grain production. Even with the best agronomic practices, only 30-40 percent of applied nitrogen is actually utilized by the crop. Availability of nitrogen is a determinant factor for the growth and yield of plants. Lowland rice is noted for the efficient utilization of applied nitrogenous fertilizer as compared to upland condition and this is especially true for top dressing of nitrogen.

The low utilization efficiency of $\mathrm{N}$ fertilizers is attributed to losses like volatilization, denitrification, leaching and surface run-off. These losses can be reduced by management practices like proper timing, rate and modified forms of urea and deep placement of $\mathrm{N}$ fertilizers. Several strategies have been tried to enhance nitrogen use efficiency (NUE) in rice including split $\mathrm{N}$ application, the use of slow release $\mathrm{N}$ fertilizers and nitrification inhibitors (NIs). Deep placement of $\mathrm{N}$ briquette at 8-10 $\mathrm{cm}$ depth of soil can save $30 \% \mathrm{~N}$ compared to Prilled Urea (PU), increases absorption rate, improves soil health and ultimately increases rice yield (Savant et al., 1991). The present study was undertaken to evaluate the effect of PU, Urea briquette and Urea briquette in combination with organics on root growth and Nitrogen losses in rice field.

\section{Materials and Methods}

\section{Site description}

An experiment was conducted under field conditions during kharif 2017 at the Research cum Instructional Farm, Indira Gandhi Krishi Vishwavidyalaya, Raipur (C.G) situated on National highway No. 6 in Eastern part of Raipur city and located between $20^{\circ} 4^{\prime}$ 'North latitude and $81^{\circ} 39^{\prime}$ 'East longitudes with an altitude of $293 \mathrm{~m}$ above mean sea level.The region comes under dry and sub-humid climatic condition. The average annual rainfall of the area is $1400-1600 \mathrm{~mm}$. The weather data during experimental period was collected from the meteorological observatory located at Labhandi (IGKV), Raipur. Major precipitation occurs between June and December (about 5-6 Months) which is the main rice growing season. The hottest and coolest months are May and December, respectively. Rice variety "Rajeshwari"was used as a test crop.

\section{Experimental soil}

The experimental soil (Vertisol) is fine montmorillonitic, hyperthermic, chromustert, locally called as Kanhar and is identified as Arang II series. The physico-chemical properties of the experimental soil are presented in Table 1.

\section{Experiment design}

The Experimental details are as follows:-

\section{Treatment details}

\section{Fertilizer application}

The recommended dose of Phosphorus and Potassium fertilizers @ 60:40 kg/ha $\left(\mathrm{P}_{2} \mathrm{O}_{5}: \mathrm{K}_{2} \mathrm{O}\right)$ was applied to the respective plots in the form of SSP and MOP as basal dose at the time of planting. Considering 
recommended dose of nitrogen @ 100 kg/ha. using urea one-third nitrogen was applied as basal dose, another one-third applied at maximum tillering and rest one-third nitrogen was applied at panicle initiation stage.

\section{Urea briquettes application}

\section{Formation of urea briquette}

Urea briquettes were made by physical modification of normal urea fertilizer. Its nature and properties are similar to that of urea but it is manufactured in pillow shaped structure and condensed with some conditions for slow hydrolysis. Each briquette weighed around $2.5 \mathrm{~g}$ with $46 \% \mathrm{~N}$ content similar to that of PU.

\section{Formation of urea briquette with organics (FYM, neem cake, vermicompost)}

These briquettes were prepared similarly to that of plain urea briquettes preparation but with some modification that $25 \%$ volume were replaced by organics (FYM, neem cake, vermicompost). Weight of each urea+FYM briquettes was $2.2 \mathrm{~g}$, urea+neem cake briquettes was $2.3 \mathrm{~g}$ and urea+vermicompost briquettes was $2.2 \mathrm{~g}$ per briquette.

\section{Deep placement of urea briquettes}

Full dose of Urea briquettes on weight basis were applied after 10 days of transplanting. For N application through USG @ 100, 75 and 50 percent RDF, one USG of $2.4 \mathrm{~g}$ size was employed for every five to six (avg.5.5) hills, seven to eight (avg. 7.3) hills and 11 hills, respectively. In case of urea briquette with organics (FYM, neem cake, vermicompost) one briquette was employed for every five to six (avg. 5.5) hills (Figure 1-3). The granules were deep placed in the puddled soil by hand and leveled immediately after placement.

\section{Statistical analyses}

\section{Observations taken}

\section{Root growth parameters}

Theroot sampling was done with the help of core sampler. The various rooting parameters were analyzed in laboratory.

\section{Root volume (ml plant ${ }^{-1}$ )}

Water displacement method - by dipping the properly washed roots in a $1000 \mathrm{ml}$ measuring cylinder containing water up to a certain point, root volume was determined by water displacement. The root volume was measured at depth $0-20 \mathrm{~cm}$ at 30, 60 and 90 DAT. The plant sample was uprooted with root by cylindrical shaped root sampler without damaging the root. Before measuring the root volume, the root was washed with tap water and then with hydrogen peroxide for complete removal of soil from root.

\section{Root weight (g)}

The clean roots were oven dried at $60^{\circ} \mathrm{C}$ and weight was measured.

\section{Nitrogen losses}

The nitrogen losses were studied by performing Ammonical nitrogen $\left(\mathrm{NH}_{4}{ }^{+}-\mathrm{N}\right)$ and Nitrate nitrogen $\left(\mathrm{NO}_{3}-\mathrm{N}\right)$ analysis in soil water (leachates). Leachates were collected by installing piezometer. PVC pipes $(2.5 \mathrm{~cm}$ in diameter and $50 \mathrm{~cm}$ in length) with sealed bottoms were installed in each field plot to collect drainage water from the saturated soil. pipes were perforated 66 times within $20 \mathrm{~cm}$ from the bottom of the pipe. The porous zone of the pipe was wrapped with nylon textile to prevent sand in-filling. Comparison was done for the inorganic $\mathrm{N}$ leaching in $20 \mathrm{~cm}$ depth. The pipes were installed at depth of $20 \mathrm{~cm}$ 
from the surface to the uppermost pore. The leachates accumulated in these pipes were collected at 3, 5 and 7 days after each dose of fertilizer application and the inorganic nitrogen in the form of $\mathrm{NH}_{4}-\mathrm{N}$ and $\mathrm{NO}_{3}-\mathrm{N}$ were analyzed.

The data collected from field observations and those recorded in laboratory were subjected to statistical analysis by standard analysis of variance technique. For significant treatment effects, standard error of means $(\mathrm{SEm} \pm)$ and critical differences were calculated at 5 per cent level of significance.

\section{Results and Discussion}

Effect of different nitrogen levels and sources on nitrogen losses in irrigated rice field

Nitrogen losses in irrigated rice field were significantly influenced by the treatments. The observations found are presented in Table 2 and 3 as well as Figure 4 and 5. The results revealed that highest concentration of $\mathrm{NH}_{4}$ Nand $\mathrm{NO}_{3}$-Nin leachate was recorded in treatment $\mathrm{T} 8 \quad[100 \% \quad \mathrm{~N}$ (RDF) through urea+100\% PK (RDF)] whereas lowest value was recorded in T9 [Urea+FYM briquettes $(75: 25)+100 \%$ PK(RDF)] followed by T10 and T11. Overall results suggests that the treatments involving application of urea+organics briquettes minimized the nitrogen losses in the form of $\mathrm{NH}_{4}$-Nand $\mathrm{NO}_{3}$-Nin leachate and among them urea+FYM briquette application resulted in minimum Nitrogen losses. The concentration of nitrates and ammonia found in leachates in treatments $\mathrm{T} 9, \mathrm{~T} 10$ and $\mathrm{T} 11$ were found significantly lower compared to rest of the treatments. The results obtained collaborated well with the findings of Vyas et al., (1991), Cameron et al., (2013), Fanqiao Meng et al., (2014) and Lihong Xue et al., (2014). Similar findings were reported by Omar et al., (2015) whereammonium and nitrate leaching losses during 30 days of the leaching experiment were highest in urea alone than in urea with clinoptilolite, zeolite and compost treatments.

\section{Experiment design}

\begin{tabular}{|l|l|}
\hline Location & Instructional cum Research Farm, I.G.K.V. Raipur \\
\hline Soil Type & Vertisols \\
\hline Season & Kharif 2017 \\
\hline Crop & Rice \\
\hline Variety & Rajeshwari \\
\hline Treatment & 11 \\
\hline Design & Randomized complete blockdesign \\
\hline Replications & Four \\
\hline Net Plot size & $7 \mathrm{~m} \times 2 \mathrm{~m}\left(14 \mathrm{~m}^{2}\right)$ \\
\hline Spacing & $20 \mathrm{~cm} \times 10 \mathrm{~cm}$ \\
\hline RDF & $\mathbf{1 0 0 : 6 0 : 4 0 ~ k g / h a ~}\left(\mathbf{N}: \mathbf{P}_{\mathbf{2}} \mathbf{O}_{\mathbf{5}}: \mathbf{K} \mathbf{K} \mathbf{O}\right)$ \\
\hline
\end{tabular}




\section{Treatment details}

\begin{tabular}{|l|l|}
\hline Notations & Treatments \\
\hline T1 & $50 \% \mathrm{~N}$ through USG+ 50\% PK (RDF) \\
\hline T2 & $75 \% \mathrm{~N}$ through USG + 50\% PK (RDF) \\
\hline T3 & $100 \% \mathrm{~N}$ through USG + 50\% PK (RDF) \\
\hline T4 & $100 \% \mathrm{~N}$ through USG+ 100\% PK (RDF) \\
\hline T5 & $50 \% \mathrm{NPK}(\mathrm{RDF})$ \\
\hline $\mathrm{T} 6$ & $75 \% \mathrm{~N}(\mathrm{RDF})$ through urea + 50\% PK (RDF) \\
\hline $\mathrm{T} 7$ & $100 \% \mathrm{~N}(\mathrm{RDF})$ through urea + 50\% PK(RDF) \\
\hline $\mathrm{T} 8$ & $100 \% \mathrm{~N}(\mathrm{RDF})$ through urea + 100\% PK (RDF) \\
\hline T9 & Urea + FYM USG (75:25 volume basis)+ 100\% PK (RDF) \\
\hline T10 & Urea+Vermicompost USG (75:25 volume basis)+100\% PK (RDF) \\
\hline T11 & Urea +Neem cake USG (75:25 volume basis)+100\% PK (RDF) \\
\hline
\end{tabular}

*USG $=$ Urea Super Granules (Briquettes)

$\mathrm{RDF}=$ Recommended dose of fertilizer @ 100:60:40 Kg N:P $\mathrm{O}_{5}: \mathrm{K}_{2} \mathrm{O} \mathrm{ha}^{-1}$

Table.1 Physico-chemical properties of experimental soil

\begin{tabular}{|c|c|c|c|}
\hline \multicolumn{2}{|c|}{ Particulars } & Values & Method \\
\hline \multicolumn{4}{|c|}{ I. Physical properties } \\
\hline 1 & Sand $(\%)$ & 19 & \multirow[t]{3}{*}{ International pipette method (Piper 1966). } \\
\hline 2 & Silt $(\%)$ & 32 & \\
\hline 3 & Clay $(\%)$ & 49 & \\
\hline 4 & Soil textural class & \multicolumn{2}{|l|}{ Clayey } \\
\hline 5 & Bulk density $\left(\mathrm{Mg} \mathrm{m}^{-3}\right)$ & 1.51 & Williams and Steinbergs (1959). Turbidimetrically. \\
\hline \multicolumn{4}{|c|}{ II. Chemical properties } \\
\hline 1 & $\mathrm{pH}(1: 2.5)$ & 7.48 & Glass electrode pH meter Jackson.(1973) \\
\hline 2 & $\mathrm{EC}\left(\mathrm{dSm}^{-1}\right.$ at $\left.25^{0} \mathrm{C}\right)$ & 0.16 & Solubridge conductivity method (Black1965). \\
\hline 3 & Organic carbon $(\%)$ & 0.56 & Rapid titration method (Walkley and Black's 1965). \\
\hline 4 & Available $\mathrm{N}\left(\mathrm{kg} \mathrm{ha}^{-1}\right)$ & 199 & Alkaline permanganate method (Subbiah and Asija, \\
\hline 5 & Available $\mathrm{P}_{2} \mathrm{O}_{5}\left(\mathrm{~kg} \mathrm{ha}^{-1}\right)$ & 14.97 & Sodium bicarbonate (Olsen et al., 1954) \\
\hline 6 & Available $\mathrm{K}_{2} \mathrm{O}\left(\mathrm{kg} \mathrm{ha}^{-1}\right)$ & 386.2 & Ammonium acetate method (Jackson 1967). \\
\hline 7 & Available $\mathrm{B}\left(\mathrm{mg} \mathrm{kg}^{-1}\right)$ & 1.54 & Berger and Truog (1939) \\
\hline 8 & Available S $\left(\mathrm{kg} \mathrm{ha}^{-1}\right)$ & 17.76 & Williams and Steinbergs (1959). Turbidimetrically. \\
\hline
\end{tabular}


Table.2 Effect of different nitrogen levels and sources on losses of $\mathrm{NH}_{4}-\mathrm{N}$

\begin{tabular}{|c|c|c|c|c|c|c|c|c|c|}
\hline \multirow[t]{3}{*}{ Treatments } & \multicolumn{9}{|c|}{ Concentration of $\mathrm{NH}_{4}-\mathrm{N}$ in leachates $(\mathrm{mg} / \mathrm{L})$} \\
\hline & \multicolumn{3}{|c|}{$\begin{array}{l}\text { Fertilizer application at } \\
10 \text { DAT }\end{array}$} & \multicolumn{3}{|c|}{$\begin{array}{l}\text { Fertilizer application at } \\
\text { 30 DAT }\end{array}$} & \multicolumn{3}{|c|}{$\begin{array}{l}\text { Fertilizer application at } \\
50 \text { DAT }\end{array}$} \\
\hline & $\begin{array}{l}\text { After } 3 \\
\text { Days }\end{array}$ & $\begin{array}{l}\text { After } 5 \\
\text { Days }\end{array}$ & $\begin{array}{l}\text { After } 7 \\
\text { Days }\end{array}$ & $\begin{array}{l}\text { After } 3 \\
\text { Days }\end{array}$ & $\begin{array}{l}\text { After } 5 \\
\text { Days }\end{array}$ & $\begin{array}{l}\text { After } 7 \\
\text { Days }\end{array}$ & $\begin{array}{l}\text { After } 3 \\
\text { Days }\end{array}$ & $\begin{array}{l}\text { After } 5 \\
\text { Days }\end{array}$ & $\begin{array}{l}\text { After } \\
7 \text { Days }\end{array}$ \\
\hline T1 & 0.48 & 0.73 & 0.69 & 0.68 & 0.65 & 0.61 & 0.59 & 0.58 & 0.45 \\
\hline $\mathbf{T 2}$ & 0.56 & 0.73 & 0.68 & 0.67 & 0.68 & 0.71 & 0.69 & 0.67 & 0.63 \\
\hline T3 & 0.98 & 0.73 & 0.70 & 0.69 & 0.70 & 0.73 & 0.70 & 0.68 & 0.65 \\
\hline $\mathbf{T 4}$ & 0.98 & 0.97 & 0.83 & 0.81 & 0.82 & 0.81 & 0.83 & 0.80 & 0.78 \\
\hline T5 & 1.12 & 1.02 & 0.90 & 1.72 & 1.52 & 1.22 & 1.62 & 1.42 & 1.13 \\
\hline T6 & 1.12 & 1.18 & 0.93 & 1.93 & 1.82 & 1.12 & 1.82 & 1.72 & 1.22 \\
\hline T7 & 1.12 & 1.20 & 0.98 & 2.13 & 2.03 & 1.32 & 2.03 & 1.88 & 1.23 \\
\hline T8 & 1.40 & 1.94 & 1.03 & 2.27 & 2.21 & 1.52 & 2.24 & 2.20 & 1.42 \\
\hline T9 & 0.56 & 0.56 & 0.42 & 0.42 & 0.46 & 0.47 & 0.40 & 0.40 & 0.38 \\
\hline T10 & 0.56 & 0.56 & 0.48 & 0.76 & 0.79 & 0.67 & 0.65 & 0.63 & 0.53 \\
\hline T11 & 0.56 & 0.70 & 0.56 & 0.78 & 0.82 & 0.70 & 0.67 & 0.66 & 0.56 \\
\hline $\begin{array}{l}\text { CD }(P= \\
0.05)\end{array}$ & 0.062 & 0.082 & 0.018 & 0.123 & 0.113 & 0.078 & 0.118 & 0.118 & 0.071 \\
\hline
\end{tabular}

Table.3 Effect of different nitrogen levels and sources on losses of $\mathrm{NO}_{3}-\mathrm{N}$

\begin{tabular}{|c|c|c|c|c|c|c|c|c|c|}
\hline \multirow[t]{3}{*}{ Treatments } & \multicolumn{9}{|c|}{ Concentration of $\mathrm{NO}_{3}-\mathrm{N}$ in leachates $(\mathrm{mg} / \mathrm{L})$} \\
\hline & \multicolumn{3}{|c|}{$\begin{array}{l}\text { Fertilizer application at } \\
10 \text { DAT }\end{array}$} & \multicolumn{3}{|c|}{$\begin{array}{l}\text { Fertilizer application at } \\
\text { 30 DAT }\end{array}$} & \multicolumn{3}{|c|}{$\begin{array}{l}\text { Fertilizer application at } \\
50 \text { DAT }\end{array}$} \\
\hline & $\begin{array}{l}\text { After } 3 \\
\text { Days }\end{array}$ & $\begin{array}{l}\text { After } 5 \\
\text { Days }\end{array}$ & $\begin{array}{l}\text { After } 7 \\
\text { Days }\end{array}$ & $\begin{array}{l}\text { After } 3 \\
\text { Days }\end{array}$ & $\begin{array}{l}\text { After } 5 \\
\text { Days }\end{array}$ & $\begin{array}{l}\text { After } 7 \\
\text { Days }\end{array}$ & $\begin{array}{l}\text { After } \\
3 \text { Days }\end{array}$ & $\begin{array}{l}\text { After } 5 \\
\text { Days }\end{array}$ & $\begin{array}{l}\text { After } 7 \\
\text { Days }\end{array}$ \\
\hline T1 & 0.56 & 0.98 & 0.94 & 0.98 & 0.98 & 0.95 & 0.97 & 0.96 & 0.94 \\
\hline $\mathbf{T} 2$ & 0.56 & 1.26 & 0.94 & 1.00 & 1.00 & 0.98 & 0.99 & 0.98 & 0.96 \\
\hline T3 & 1.12 & 2.80 & 1.96 & 1.96 & 1.96 & 1.82 & 1.80 & 1.80 & 1.78 \\
\hline $\mathbf{T 4}$ & 1.12 & 2.80 & 2.30 & 2.30 & 1.98 & 1.98 & 1.98 & 1.86 & 1.98 \\
\hline T5 & 1.12 & 3.78 & 3.22 & 4.20 & 4.06 & 2.38 & 3.92 & 2.50 & 1.98 \\
\hline T6 & 1.12 & 4.41 & 3.50 & 4.06 & 4.20 & 2.80 & 5.02 & 3.64 & 2.24 \\
\hline T7 & 1.12 & 4.95 & 3.86 & 5.08 & 4.88 & 4.00 & 5.06 & 4.00 & 2.46 \\
\hline T8 & 1.68 & 5.15 & 4.06 & 5.28 & 5.08 & 4.20 & 5.26 & 4.20 & 2.66 \\
\hline T9 & 0.56 & 0.88 & 0.78 & 0.75 & 0.77 & 0.75 & 0.77 & 0.74 & 0.70 \\
\hline T10 & 0.56 & 0.98 & 0.88 & 0.85 & 0.87 & 0.85 & 0.84 & 0.86 & 0.84 \\
\hline T11 & 0.56 & 0.98 & 0.93 & 0.90 & 0.92 & 0.90 & 0.89 & 0.91 & 0.89 \\
\hline $\begin{array}{l}\text { CD }(P= \\
0.05)\end{array}$ & 0.057 & 0.240 & 0.154 & 0.238 & 0.232 & 0.128 & 0.260 & 0.202 & 0.093 \\
\hline
\end{tabular}


Table.4 Effect of different nitrogen levels and sources on root growth

\begin{tabular}{|c|c|c|c|c|c|c|}
\hline \multirow[t]{2}{*}{ Treatment } & \multicolumn{3}{|c|}{ Root dry weight (g/hill) } & \multicolumn{3}{|c|}{ Root volume $\left(\mathrm{cm}^{3} / \mathrm{hill}\right)$} \\
\hline & $30 \mathrm{DAT}$ & 60 DAT & 90 DAT & $30 \mathrm{DAT}$ & $60 \mathrm{DAT}$ & $90 \mathrm{DAT}$ \\
\hline T1 & 0.68 & 4.80 & 5.10 & 7.85 & 31.92 & 33.11 \\
\hline $\mathrm{T} 2$ & 0.76 & 5.82 & 6.23 & 8.15 & 37.83 & 40.49 \\
\hline T3 & 1.10 & 6.99 & 7.59 & 11.30 & 38.93 & 44.74 \\
\hline $\mathrm{T} 4$ & 1.28 & 8.42 & 9.42 & 12.26 & 50.52 & 56.52 \\
\hline T5 & 0.69 & 4.78 & 4.98 & 8.90 & 30.83 & 32.89 \\
\hline T6 & 0.80 & 5.73 & 5.99 & 9.50 & 33.80 & 35.34 \\
\hline $\mathrm{T} 7$ & 1.12 & 5.99 & 6.32 & 12.20 & 38.10 & 41.08 \\
\hline $\mathrm{T} 8$ & 1.29 & 6.35 & 7.00 & 13.00 & 38.70 & 42.68 \\
\hline T9 & 1.30 & 8.62 & 9.74 & 13.30 & 51.84 & 56.52 \\
\hline T10 & 0.95 & 7.74 & 9.42 & 10.40 & 44.40 & 52.44 \\
\hline T11 & 1.10 & 7.59 & 8.29 & 11.15 & 44.38 & 45.11 \\
\hline $\begin{array}{c}\mathrm{CD}(\mathbf{P}= \\
\mathbf{0 . 0 5})\end{array}$ & 0.05 & 0.31 & 0.33 & 0.53 & 1.92 & 2.04 \\
\hline
\end{tabular}

Fig.1 Layout for Briquette application (a) Urea briquette with organics and also for $100 \%$ RDF$\mathrm{N}$ through USG (b) 75\% RDF-N through USG (c) 50\% RDF-N through USG (d) Depth of application of USG

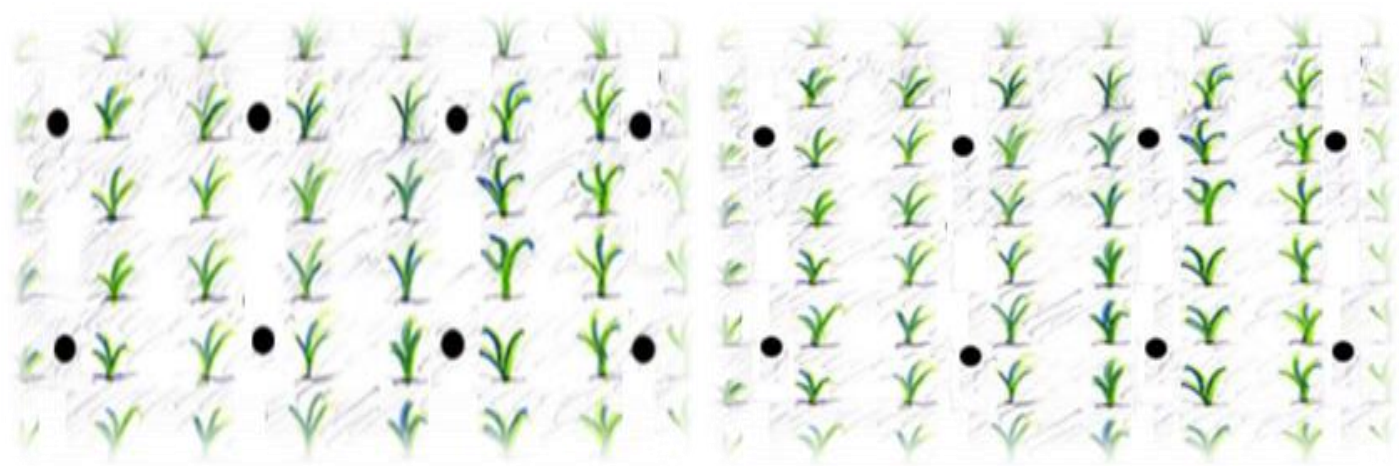

(a)

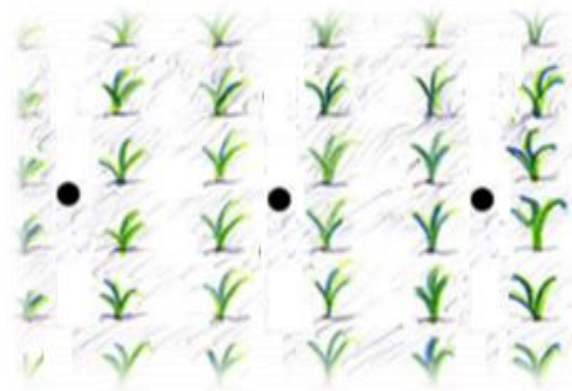

(c) (b)

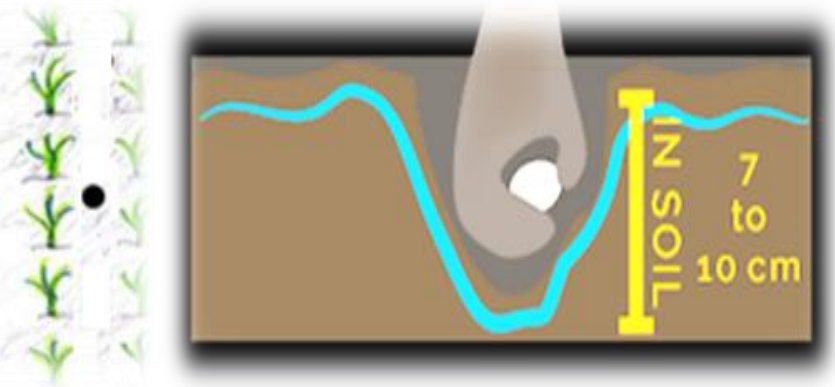

(d) 
Fig.2 Piezometer installation (a) Making hole in plot to install piezometer (b) Installed piezometer (c) field photograph with piezometers installed

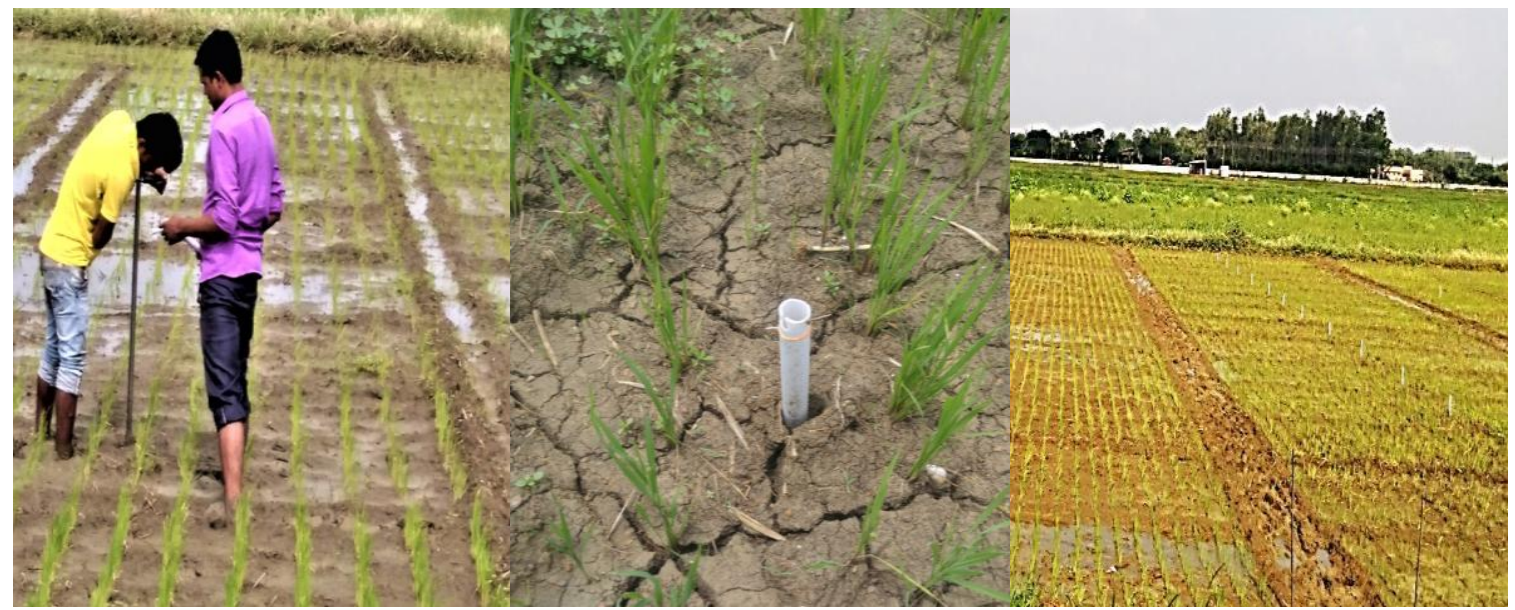

(a)

(b)

(c)

Fig.3 Root sampling using core sampler

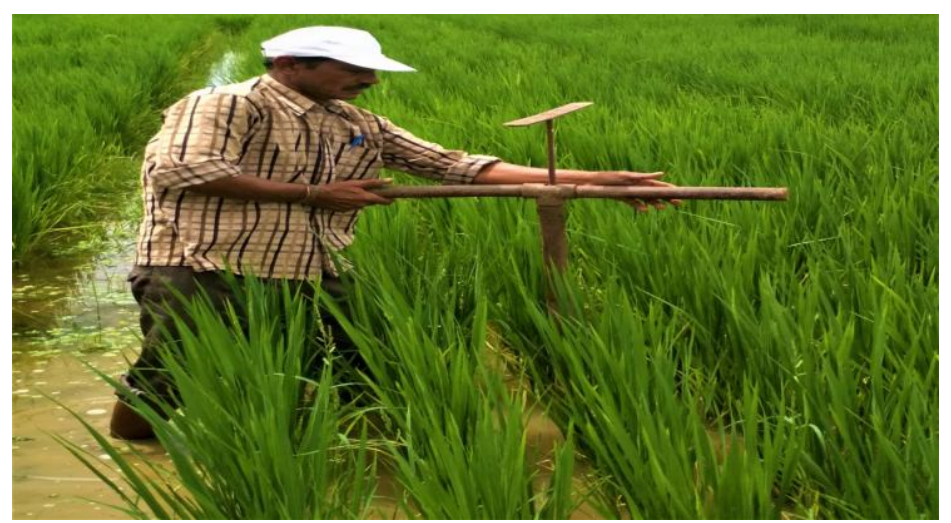

Fig.4 Effect of different nitrogen levels and sources on losses of $\mathrm{NH}_{4}-\mathrm{N}$

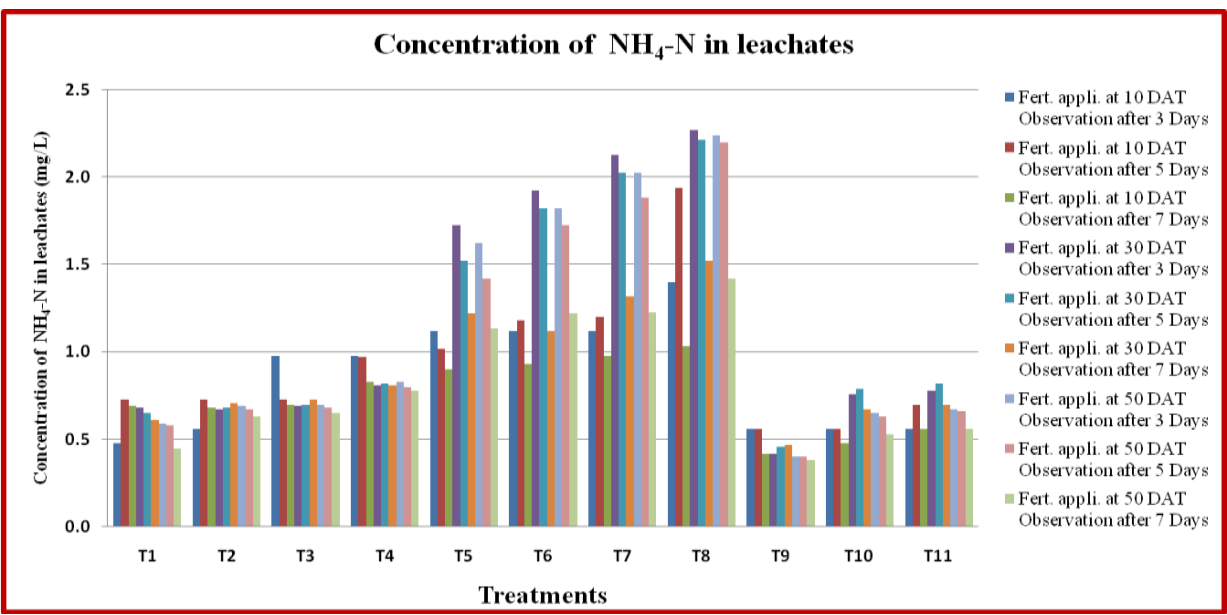


Fig.5 Effect of different nitrogen levels and sources on losses of $\mathrm{NO}_{3}-\mathrm{N}$

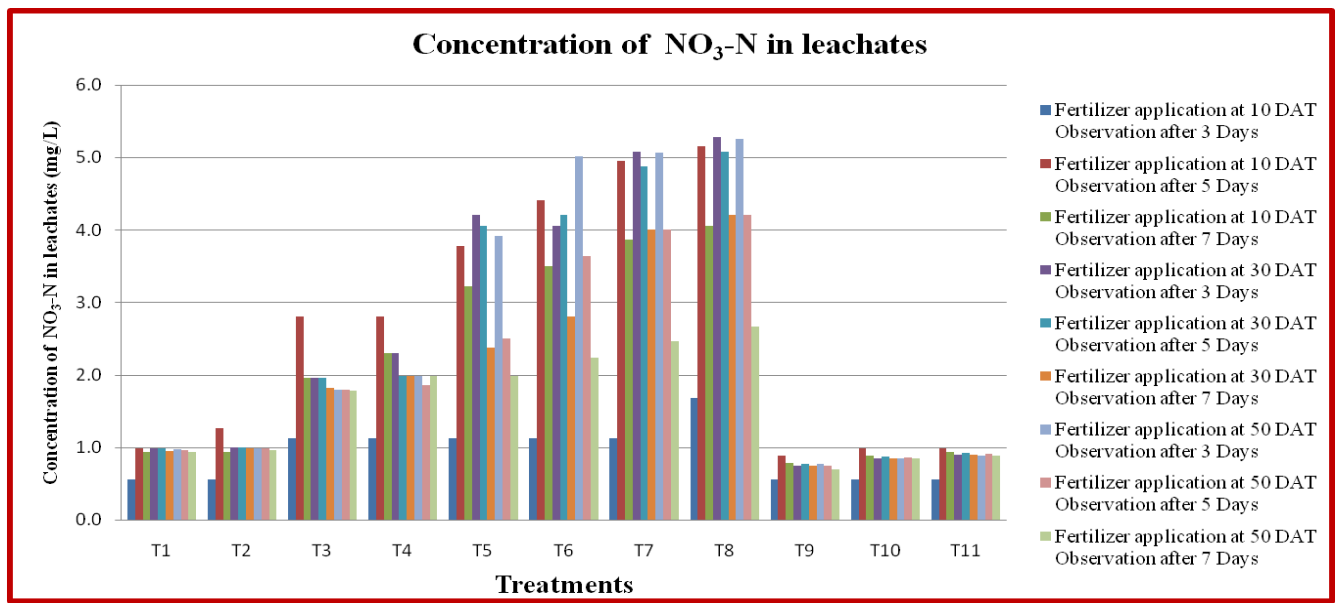

Fig.6 Effect of different nitrogen levels and sources on root growth

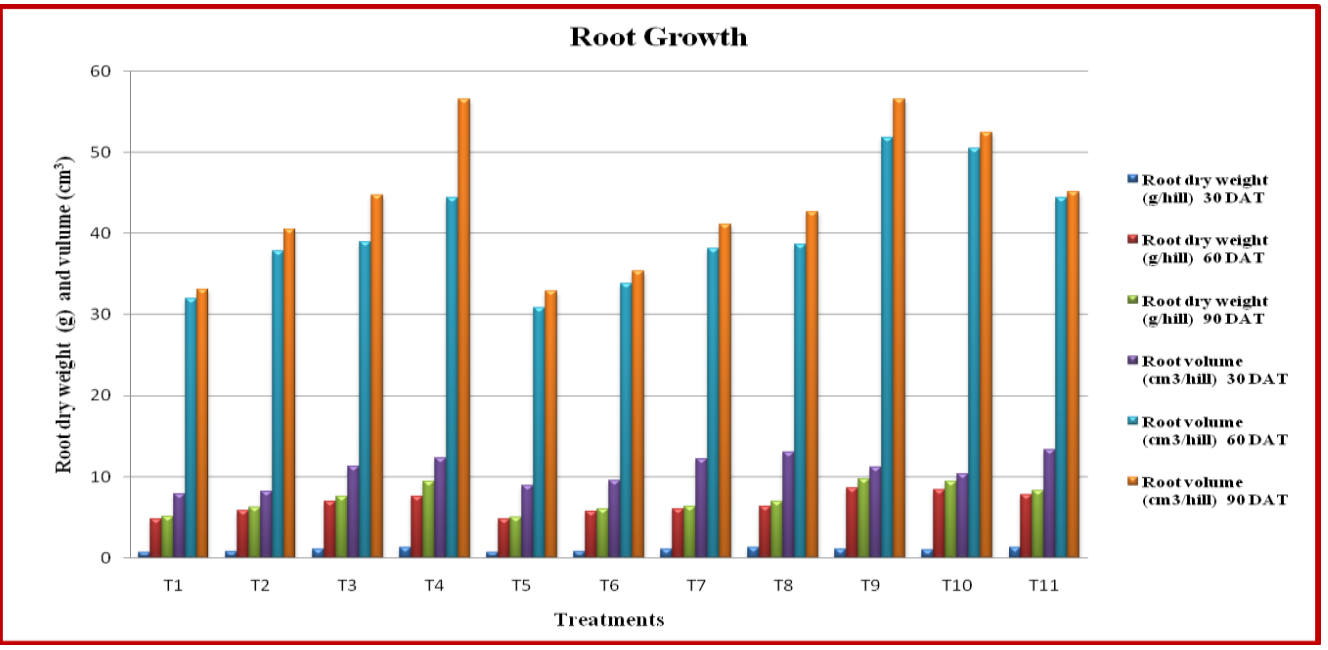

Effect of different nitrogen levels and sources on root dry weight $\left(\mathrm{g} \mathrm{hill}{ }^{-1}\right)$

There was a progressive increase in root dry weight with the advancement of crop growth stage up to 90 DAT. The data of dry weight of root in $\mathrm{g} \mathrm{hill}^{-1}$ at $30 \mathrm{DAT}, 60 \mathrm{DAT}$ and 90 DAT is presented in Table 4 and Figure 6. The highest dry weight (1.30 at 30 DAT, 8.62 at $60 \mathrm{DAT}$ and 9.74 at $90 \mathrm{DAT}^{\mathrm{D}} \mathrm{g}$ hill $^{-1}$ was recorded under treatment T9[Urea+FYM briquettes(75:25)+100\% PK(RDF)]followed by $\mathrm{T} 4[100 \% \mathrm{~N}$ through USG+100\% $\mathrm{PK}(\mathrm{RDF})]$ whereas, lowest value was observed inT5 [50\% $\mathrm{N}$ (RDF) through urea+50\% PK(RDF)]. The observations at flowering stage suggests that application of RDF, USG and urea briquettes in combination with organics produced significantly higher dry-matter and dry weight of root than the control.Similar findings have been reported by Islam et al., (2011) and Ahmed et al., (2005).

Effect of different nitrogen levels and sources on root volume $\left(\mathrm{cm}^{3} \mathrm{hill}^{-1}\right)$

The data of root volume $\left(\mathrm{cm}^{3}\right.$ hill $\left.^{-1}\right)$ at 30 DAT, 60 DAT and 90 DAT is presented in Table 4 and Figure 6 . The highest root 
volume $\left(\mathrm{cm}^{3}\right.$ hill $\left.^{-1}\right)$ (13.30 at 30 DAT, 51.84 at 60 DAT and 56.52 at 90 DAT) was recorded under treatment T9[Urea+FYM briquettes $(75: 25)+100 \% \quad \mathrm{PK}(\mathrm{RDF})]$ followed by $\mathrm{T} 4[100 \% \mathrm{~N}$ through USG+100\% $\mathrm{PK}(\mathrm{RDF})]$ whereas, lowest value was observed in $\mathrm{T} 5$ [50\% N (RDF) through urea+50\% PK(RDF)]. Over all the effect of different nitrogen levels and sourceswas found statistically significant on root volume. Similar findings were reported by Singh et al., (1997) and Sharma et al., (2016).

The combination of organics like FYM, vermicompost and neem cake in urea briquettes in treatments $\mathrm{T} 9, \mathrm{~T} 10$ and $\mathrm{T} 11$ respectively provided better physic-chemical and biological soil condition to plant and briquette formation reduced the surface area of applied $\mathrm{N}$ - fertilizer, also deep placement of briquettes induced slow release of nitrogen, thusreducing the nitrogen losses in the form of ammonia and nitrates in soil water leachate, thereby higher nitrogen uptake and ultimtely produced higher root biomass. The treatment T9 performed better due to slow and regular release of nitrogen as briquettes with organics provide better nutrient use efficiency and minimum nutrient losses so that plant can easily uptake nutrient in their critical growth period. Similar result was reported by Mishra et al., (1999), Laxminarayana (2006), Yadav et al., (2014) and Sunitha et al., (2010) and Chesti et al., (2015). Overall findings indicate that, Urea+FYM briquette application among different sources of fertilizer nitrogen was found most suitable for irrigated ricein terms of better root growth and minimum nitrogen losses.

\section{Acknowledgements}

Authors are thankful to the Head, Department of Soil Science and Agricultural Chemistry, Dean, College of Agriculture, Indira Gandhi
Krishi Vishwavidyalaya, Raipur (C.G) for providing the necessary facilities in accomplishing the research work.

\section{References}

Ahmed, M., Islam, Md. M. and Paul, S. K. 2005. Effect of nitrogen on yield and other plant characters of local $\mathrm{T}$. aman rice, var. jatai. Research Journal of Agriculture and Biological Sciences, 1(2): 158-161.

Aulakh, M. S., Doran, J. W., and Mosier, A. R. (1992). Soil denitrification: Significance,measurement, and effects of management. Adv. Soil Sci. 18:1-57.

Bajpai, R.K., Chitale, S., Upadhyay, S.K. and Urkurkar, J.S. 2006. Long-term studies on soil physico-chemical properties and productivity of rice-wheat system as influenced by integrated nutrient management in Inceptisol of Chhattisgarh. J.Indian Soc. Soil Sci. 54(1): 24-29.

Cassman, K.G.S., Peng, S., Olk, D.C., Ladha, J.K., Reichardt, W., Doberman, A., Singh, U. 1998. Opportunities for increased nitrogen use efficiency from improved resource management in irrigated rice systems. Field Crops Res. 56:7-38.

Cameron, K.C., Di, H.J., Moir, J.L. 2013. Nitrogen losses from the soil/plant system. Annals of Applied Biology, 162(2):145-173.

Chesti, M.H., Kohli, A., Mujtaba, A., Sofi, J.A., Nazir Q.T., Peer, Q.J.A., Dar, M.A. and Bisati, I.A. 2015. Effect of integrated application of inorganic and organic sources on, soil properties, yield and nutrient uptake by rice (Oryza sativa L.) in intermediate zone of Jammu and Kashmir. J. of the Indian Society of Soil Sci. 63(1): 88-92.

Choudhury, A., Bhuiyan, N.I., Hashem, M.A., Matin, M.A. 2009. Nitrogen fertilizers deep placement in wetland rice. Bangladesh Research Publication Journal 2(2): 499-505.

Ciampitti, I.A. and T.J. Vyn. 2012. Physiological perspectives of changes over time in maize yield dependency on nitrogen uptake and associated nitrogen efficiencies: A review. Field Crops Res. 133: 48-67.

Das, S. and Singh, T.A. 1994. Nitrogen use efficiency by rice and flood water 
parameters as affected by fertilizer placement techniques. Journal of Indian Society of Soil Science 42(1): 46-50.

Derrick, B.E., Etienne, I., Mathusalem, K. 2017 Comparative Study of Urea in Prilled and Briquette Forms on Rice Production in Marshlands of Rwanda. J Fert. Pest. 8: 178.

Gomez, A.K and Gomez, A.A. 1984. Statistical Procedures for Agriculture Res. A wileyInter Sci. Publication. Johan Wiley and Sons, New York.

Hasan, S.M. 2007. Effect of level of urea supergranules on the performance of $\mathrm{T}$. aman rice. M. Sc. Ag. Thesis in Agronomy, BAU, Mymensingh.P:72-85.

Islam, M.S., Rahman, F. and Hossain A.T.M.S. 2011. Effects of NPK Briquette on Rice (Oryza sativa) in Tidal Flooded Ecosystem. The Agriculturists 9(1\&2): 37-43(2011) ISSN-1729-5211 A Scientific Journal of Krishi Foundation.

Jena, D., Misra, C., Bandyopadhyay, K.K. 2003. Effect of prilled urea and urea super granules on dynamics of ammonia volatilization and $\mathrm{N}$ use efficiency of rice. Journal of Indian Society of Soil Science 51(3): 257-261.

Darade, A.B. and K.B. Bankar. 2009. Effect of Urea-DAP briquettes and zinc levels on nitrogen, phosphorus and potassium uptake and yield of hybrid rice. Int. J. Agric.Sci. 5(2): 510-512.

Devi Joshna M.C., Anurag, Surekha, K., Bajpai, R.K. and Kumar R. 2017. Studies on Nitrogen use efficiency in irrigated rice as influenced by various sources of Nitrogen. International Journal of Chemical Studies, 5(4): 1278-1281.

Gupta, V., Sharma, R.S., and Vishvakarma, S.K. 2006. Long-term effect of integrated nutrient management on yield sustainability and soil fertility of rice (Oryza sativa)-wheat (Triticum aestivum) cropping system. Indian Journal of Agronomy, 51: 160-164.

Hanway, J. J. and Heidel, H. 1952. Soil analyses methods as used in Iowa State College Soil Testing Laboratory. Iowa Agric, 57: 1-31.

Kapoor, V., Singh, U., Patil, S. K., Magre, H., Shrivastava, L. K., Mishra, V. N., Das, R. O. Samadhiya, V. K., Sanabria J. and Diamond, R. 2008. Rice Growth, Grain Yield and Floodwater Nutrient Dynamics as Affected by Nutrient Placement Method and Rate. Agronomy Journal. 100(3): 526-536.

Kumar, A., Meena, R.N., Yadav, L. and Gilotia, Y.K., 2014. Effect of organic and inorganic sources of nutrient on yield, yield attributes and nutrient uptake of rice cv. PRH-10. The Bioscan, 9(2): 595-597.

Laxminarayana K and Patiram 2006. Effect of integrated use of inorganic, biological and organic manures on rice productivity and soil fertility in Ultisols of Mizoram. J. Indian Soc. Soil Sci. 54(2): 213-220.

Lihong Xue, Yingliang $\mathrm{Yu}$ and Linzhang Yang 2014.Maintaining yields and reducing nitrogen loss in rice-wheat rotation system in Taihu Lake region with proper fertilizer management. Environmental Research Letters, 9(11).

Meng, F., Olesen, J.E., Sun, X., Wu,W., 2014. Inorganic Nitrogen Leaching from Organic and Conventional Rice Production on a Newly Claimed Calciustoll in Central Asia. Bond-Lamberty B, ed. PLoS ONE, 9(5): e98138. doi:10.1371/journal.pone.0098138.

Miah, I., Chowdhury, M.A.H., Sultana, R., Ahmed, I. and Saha, B.K. 2012. Effects of prilled urea and urea super granule on growth, yield and quality of BRRI dhan28. J. Agrofor. Environ., 6 (1): 57-62.

Mishra, B.K., Mishra, S., Dash, A.K., and Jena, D. 1999. Effect of time for urea super granule (USG) placement on lowland rice. Annals Agricultural Research, 20(4): 443447.

Olsen, S.R., Cole, C.V. Watnable F.S. and Dean, L.A. 1954. Estimation of available phosphorous in soils by extraction with sodium carbonate. U.S.D.A. Cir.No.933: 110.

Omar et al., 2015. Improving Ammonium and Nitrate Release from Urea Using Clinoptilolite Zeolite and Compost Produced from Agricultural Wastes. The Scientific World Journal, Article ID 574201.

Pengfei Li et. al. 2018. Nitrogen losses, use efficiency, and productivity of early rice under controlled-release urea.Journal of Agriculture, Ecosystems \& Environ., 251:78-87.

Piper, C.S. 1966. Soil and Plant Analysis, Hans. Pub. Bombay. Asian Ed. pp. 368-374. 
Rodgers, G.A. 1986. Nitrification inhibitors in agriculture. Journal of Environmental Science and Health. Part A: Environmental Science and Engineering. 21(7): 701-722.

Roy, Rinky, Bajpai, R.K. and Bachkaiya, V. 2018. Assessment of urea briquettes in combination with organics on rice productivity under irrigated conditions. Trends in Biosciences Journal.11(30):36123614.

Roy, Rinky, R.K. Bajpai, Vinay Bachkaiya, Chandan Kumar Roy, Minakshi Sahu, Neha Padhi and Ankita Tirkey. 2018. Evaluation on Impact of Use of Urea Briquettes in Combination of Organics on Nutrient Use Efficiency in Irrigated Rice. Int.J.Curr.Microbiol.App.Sci. 7(12): 14641479.

doi: https://doi.org/10.20546/ijcmas.2018.712.17 4

Savant, N.K. and Stangel, P.J. 1990. Deep placement of urea super granules in transplanted rice: principles and practices. Fertilizer Research, 25: 1-83.

Sharma, U., Subehia, S.K. and Rana, S.S., 2016. Long term effect of integrated nutrient management on yield and economics of rice (Oryza sativa L.)-wheat (Triticum aestivum L.) system in north-western Himalaya. Research on Crops, 17(2):173177.

Singh, R., Tripathi, R.P. and Sharma, J.C., 1997. Rooting pattern and yield of rice (Oryza sativa L.) as influenced by soil water regimes. Journal of the Indian Society of Soil Science, 45(4): 693-697.

Subbaiah, B.V and Asija, G.L. 1956. A rapid procedure of estimation of availablenitrogen in soils.Current Science, 65(7): 477-480.

Subbiah, S., Ramanathan, K.M. and Francis, H.J. 1979. Influence of neem cake-coated urea application on the yield and nutrient uptake by IR20 rice. International Rice Commission Newsletter, 28(2): 15-19.

Sunitha, B.P., Prakasha, H.C. and Gurumurthy, K.T. 2010. Influence of organics, inorganic and their combinations on availability, content and uptake of secondary nutrients by rice crop (Oryza sativa L.) in Bhadra Command, Karnataka. Mysore Journal of Agricultural Sciences 44(3): 509-516.

Vyas, B.N., Godrej, N.B. and Mistry, K.B. 1991: Development and evaluation of neem extract as a coating for urea fertiliser. Fertiliser News, 36(2).

Yadav, S.K. and Saha, B. 2014. Partial substitution of nitrogenous fertilizer through organics enhances yield, nutrient uptake and physiological characteristics of transplanted rice (Oryza sativaL.) integrated nutrient management after rainfed cropping sequence. Indian J. Agric. Res, 45 (4): 346 349.

Yawalkar, K. S., Agrawal, J. P. and Bokde, S. 1996. Commercial nitrogenous fertilizers. Manure and fertilizers, 8(4): 96-97.

Zhang, J., Qin, J., Yao, W., Bi1, L., Lai, T. and $\mathrm{Yu}, \mathrm{X} .2009$. Effect of long-term application of manure and mineral fertilizers on nitrogen mineralization and microbial biomass in paddy soil during rice growth stages. Plant Soil Env., 55(3): 101-10

\section{How to cite this article:}

Rinky Roy, R.K. Bajpai, VinayBachkaiya, Chandan Kumar Roy, Khagesh Joshi and Sushma. 2019. Effect of Urea Briquettes in Combination of Organics on Root Growth and Nitrogen Losses in Rice Field. Int.J.Curr.Microbiol.App.Sci. 8(01): 1463-1474. doi: https://doi.org/10.20546/ijcmas.2019.801.156 